\title{
ANALISIS PENGARUH HARI PERDAGANGAN DAN NILAI TUKAR TERHADAP INDEKS HARGA SAHAM GABUNGAN (IHSG) DI BURSA EFEK INDONESIA TAHUN 2009
}

\author{
Erric Wijaya; Fatiah Istarini
}

STIE Indonesia Banking School

Jl. Kemang Raya No. 35, Kebayoran Baru, Jakarta Selatan 12730.

akuntansi@ibs.ac.id

\begin{abstract}
Before making investment decisions, investors need to analyze the pattern of trading days which change daily because of investors' behavior in stock trading activity that affects the pattern of daily stock price movements. Changes in macro variables like exchange rates for instance, also can affect share price. To determine the influence of independent variables (day of the week effect and exchange rate) on the dependent variable (Jakarta Composite Index (JCI)), a research is conducted using multiple linear regression analysis. The initial test uses a test of normality and is resumed by testing multiple linear regression analysis and classical assumption. The hypothesis test uses t-statistics and F-statistics with a significance level of 5\%. A descriptive statistics implies that there is an effect of trading days on stock prices. However, using backward stepwise linier regression model and multivariate analysis, the result indicates that there is no effect of trading days on stock prices. Using multivariate data analysis, it is found that stock prices is influenced by exchange rate.
\end{abstract}

Keywords: trading days, exchange rate, Jakarta composite index (JCI)

\begin{abstract}
ABSTRAK
Sebelum membuat keputusan investasi, investor perlu menganalisis pola hari perdagangan yang berubah setiap harinya karena perilaku investor dalam aktivitas perdagangan saham yang mempengaruhi pola pergerakan harga saham harian. Perubahan dalam variabel makro seperti nilai tukar misalnya, juga dapat mempengaruhi harga saham. Untuk menentukan pengaruh variabel independen (hari perdagangan dan efek nilai tukar) terhadap variabel dependen (Indeks Hagra Saham Gabungan (IHSG) Jakarta), dilakukan penelitian menggunakan analisis regresi linier berganda. Uji awal menggunakan uji normalitas dilanjutkan dengan pengujian analisis regresi linier berganda dan asumsi klasik. Uji hipotesis menggunakan t-statistik dan Fstatistik dengan tingkat signifikansi 5\%. Statistik deskriptif menunjukkan bahwa terdapat pengaruh hari perdagangan terhadap harga saham. Namun, model regresi linier bertahap mundur dan analisis multivariate menunjukkan tidak ada pengaruh hari perdagangan terhadap harga saham. Berdasarkan analisis data multivariat, ditemukan bahwa harga saham dipengaruhi oleh nilai tukar.
\end{abstract}

Kata kunci: hari perdagangan, nilai tukar, Jakarta composite index (JCI) 


\section{PENDAHULUAN}

Pasar modal merupakan suatu sarana efektif dalam memperlancar proses pembangunan Negara karena dapat membantu penghimpunan dana (modal) yang dibutuhkan dunia usaha untuk ekspansi bisnis maupun investasi baru. Pasar modal dipandang menguntungkan bagi perekonomian suatu negara karena menyediakan fasilitas untuk memindahkan dana dari lender (pihak yang memiliki kelebihan dana) ke borrower (pihak yang memerlukan dana). Dengan menginvestasikan kelebihan dananya, investor mengharapkan akan memperoleh imbalan (return) dari penyerahan dana tersebut. Untuk mengetahui besarnya return yang didapat oleh investor tercermin dari tinggi atau rendahnya harga saham suatu perusahaan. Dalam pengambilan keputusan investasi, seorang investor perlu melakukan analisis terhadap pola hari perdagangan yang berubah setiap harinya. Perubahan ini disebabkan oleh perubahan perilaku investor dalam melakukan aktivitas perdagangan di bursa sehingga perubahan perilaku investor akan berpengaruh terhadap pola pergerakan harga harian saham. Perubahan variabel makro juga menjadi salah satu faktor yang mempengaruhi hal tersebut, salah satunya exchange rate yang dapat mempengaruhi harga saham.

Dari beberapa penelitian yang dilakukan pada bursa efek Amerika dan negara lainnya terdapat ketidakteraturan yang terdeteksi dalam pasar modal karena perbedaan pola pergerakan harga harian saham. Ketidakteraturan ini disebut anomali pasar. Dalam keadaan anomali, hasil yang timbul di pasar modal tidak sejalan dengan kondisi pasar modal efisien. Anomali yang terjadi pada harga saham antara lain pengaruh hari perdagangan dalam satu minggu (day of the week effect). Day of the week effect merupakan perbedaan signifikan return saham pada hari tertentu dalam satu minggu dengan pendapatan pada hari-hari perdagangan lainnya. Return saham yang diperoleh merupakan cerminan dari harga saham yang dimiliki suatu perusahaan.

Dalam penelitian ini Indeks Harga Saham Gabungan (IHSG) digunakan sebagai instrumen yang dapat menggambarkan harga saham dari seluruh perusahaan yang terdaftar di Bursa Efek Indonesia (BEI). Dari perbedaan pola hari perdagangan yang berubah setiap harinya dan perubahan variabel makro yang dapat mempengaruhi pergerakan harga saham, maka penelitian mengenai Pengaruh Hari Perdagangan Dalam Satu Minggu (Day Of The Week Effect) dan Exchange Rate Terhadap IHSG di BEI Tahun 2009 dilakukan.

Penulis merumuskan pokok permasalahan sebagai berikut: (1) Apakah hari perdagangan dalam satu minggu (day of the week effect) secara parsial berpengaruh signifikan terhadap IHSG di BEI? (2) Apakah exchange rate secara parsial berpengaruh signifikan terhadap IHSG di BEI? (3) Apakah hari perdagangan dalam satu minggu (day of the week effect) dan exchange rate secara simultan berpengaruh signifikan terhadap IHSG di BEI?

Melihat luasnya cakupan pembahasan dalam penelitian ini, penulis melakukan beberapa pembatasan masalah, yaitu: (1) Penelitian dilakukan pada Indeks Harga Saham Gabungan (IHSG) harian; (2) Periode penelitian ini dilakukan satu tahun, yaitu tahun 2009; (3) Penelitian ini mengabaikan variabel makro ekonomi lainnya, seperti inflasi, tingkat bunga, GDP dan lain-lain; (4) Harga saham yang digunakan adalah harga saham pada saat penutupan hari tersebut; (5) Nilai tukar yang digunakan adalah nilai tukar rupiah/US\$.

Berdasarkan pada perumusan masalah yang telah diuraikan di atas, tujuan penelitian ini adalah: (1) Untuk mengetahui bagaimana hari perdagangan dalam satu minggu (day of the week effect) secara parsial berpengaruh signifikan terhadap IHSG di BEI; (2) Untuk mengetahui bagaimana exchange rate secara parsial berpengaruh signifikan terhadap IHSG di BEI; (3) Untuk mengetahui bagaimana hari perdagangan dalam satu minggu (day of the week effect) dan exchange rate secara simultan berpengaruh signifikan terhadap IHSG di BEI. 


\section{Landasan Teori}

\section{Investasi}

Menurut Sunariyah (2006) investasi adalah penanaman modal untuk satu atau lebih aktiva yang dimiliki dan biasanya berjangka waktu lama dengan harapan mendapatkan keuntungan di masamasa yang akan datang. Sedangkan menurut Mankiw (2000), investasi adalah barang-barang yang dibeli oleh individu dan perusahaan untuk menambah persediaan modal mereka. Menurut ebursa.com, investasi merupakan suatu penundaan konsumsi dari masa sekarang untuk masa yang akan datang. Husnan (2009) menyatakan bahwa proyek investasi merupakan suatu rencana untuk menginvestasikan sumber-sumber daya, baik proyek raksasa ataupun proyek kecil untuk memperoleh manfaat pada masa yang akan datang. Adapun menurut Tandelilin (2010), investasi adalah komitmen atas sejumlah dana atau sumber daya lain yang dilakukan saat ini dengan tujuan memperoleh keuntungan di masa datang.

Investasi secara umum dapat dikategorikan menjadi dua. Pertama adalah real investment, yaitu investasi dalam bentuk nyata seperti investasi dalam bentuk properti, investasi komersial, dan lainlain. Kedua adalah financial investment, yaitu investasi terhadap produk-produk keuangan seperti investasi dalam bentuk tetap, antara lain deposito, obligasi ataupun dalam bentuk yang tidak tetap seperti investasi saham atau sejenisnya.

\section{Pasar Modal}

Pasar modal menurut Husnan (2009) didefinisikan sebagai pasar untuk berbagai instrumen keuangan (sekuritas) jangka panjang yang bisa diperjualbelikan, baik dalam bentuk hutang ataupun modal sendiri, baik yang diterbitkan oleh pemerintah maupun perusahaan swasta. Menurut Sunariyah (2006), pasar modal adalah suatu pasar (tempat, berupa gedung) yang disiapkan guna memperdagangkan saham-saham, obligasi-obligasi dan jenis surat berharga lainnya dengan memakai jasa para perantara pedagang efek. Menurut Tandelilin (2010), pasar modal adalah pertemuan antara pihak yang memiliki kelebihan dana dengan pihak yang membutuhkan dana dengan cara memperjualbelikan sekuritas. Berdasarkan pengertian yang ada, dapat disimpulkan bahwa pasar modal adalah tempat pertemuan antara penawaran dengan permintaan surat berharga. Di tempat inilah para pelaku pasar yaitu individu-individu atau badan usaha yang mempunyai kelebihan dana melakukan investasi dalam surat berharga yang ditawarkan oleh emiten. Sebaliknya, di tempat itu juga perusahaan yang membutuhkan dana menawarkan surat berharga dengan cara listing terlebih dahulu pada badan otoritas di pasar modal sebagai emiten.

Efisiensi pasar modal ada tiga macam. Pertama adalah efisiensi pasar bentuk lemah (weak form). Pasar dikatakan efisien dalam bentuk jika harga-harga dari sekuritas secara penuh mencerminkan (fully reflect) informasi masa lalu. Informasi masa lalu ini merupakan informasi yang sudah terjadi. Bentuk efisiensi pasar secara lemah ini berkaitan dengan teori langkah acak (random walk theory) yang menyatakan bahwa data masa lalu tidak berhubungan dengan nilai sekarang. Jika pasar efisien secara bentuk lemah, nilai-nilai masa lalu tidak dapat digunakan untuk memprediksi harga sekarang. Ini berarti bahwa untuk efisiensi pasar bentuk lemah, investor tidak dapat menggunakan informasi masa lalu untuk mendapatkan keuntungan yang tidak normal (abnormal return) (Hartono, 2003). Kedua adalah efisiensi pasar bentuk setengah kuat (semi-strong form). Pasar dikatakan efisien setengah kuat jika harga-harga sekuritas secara penuh mencerminkan (fully reflect) semua informasi yang dipublikasikan (all publicly available information) termasuk informasi di laporan keuangan perusahaan emiten. Informasi yang dipublikasikan dapat berupa informasi yang umumnya berhubungan dengan peristiwa yang terjadi di perusahaan emiten (corporate event), peraturan pemerintah atau regulator yang hanya berdampak pada harga sekuritas perusahaan yang terkena regulasi dan peraturan pemerintah yang berdampak ke semua perusahaan emiten. Dalam pasar efisien bentuk setengah kuat tidak ada investor individu ataupun kelompok dari investor dapat 
menggunakan informasi yang dipublikasikan untuk mendapatkan keuntungan tidak normal (abnormal return) dalam jangka waktu yang lama (Hartono, 2003). Ketiga adalah efisiensi pasar bentuk kuat (strong form). Pasar dikatakan efisien dalam bentuk kuat jika harga-harga sekuritas secara penuh mencerminkan (fully reflect) semua informasi yang tersedia, termasuk informasi yang privat. Jika pasar efisien dalam bentuk ini, tidak ada investor individu atau kelompok investor yang dapat memperoleh keuntungan tidak normal (abnormal return) karena mempunyai informasi privat (Hartono, 2003). Hubungan antara ketiga bentuk pasar modal efisien tersebut dapat digambarkan sebagai berikut (Gambar 1):

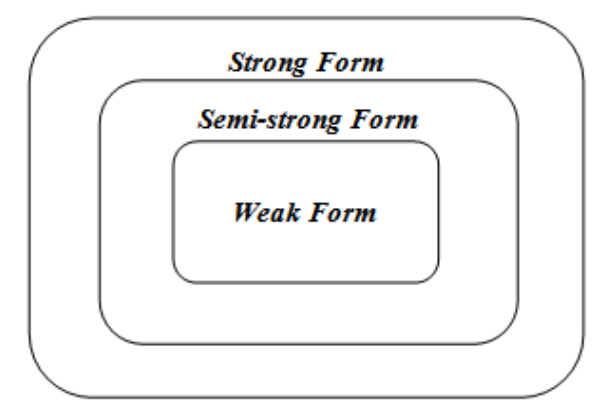

Gambar 1. Tingkatan kumulatif bentuk pasar efisien (Hartono, 2003).

\section{Saham}

Hartono (2003) mengatakan suatu perusahaan dapat menjual hak kepemilikannya dalam bentuk saham (stock). Menurut Bursa Efek Indonesia (2010), saham diartikan sebagai tanda penyertaan modal seseorang atau pihak (badan usaha) dalam suatu perusahaan atau perseroan terbatas. Dengan menyertakan modal tersebut, maka pihak tersebut memiliki klaim atas pendapatan perusahaan, klaim atas asset perusahaan dan berhak hadir dalam Rapat Umum Pemegang Saham (RUPS). Wujud saham berupa selembar kertas yang menerangkan siapa pemiliknya. Akan tetapi, sekarang ini sistem tanpa warkat sudah dilakukan di Bursa Efek Indonesia, dimana bentuk kepemilikan tidak lagi berupa lembaran saham yang diberi nama pemiliknya tetapi sudah berupa account atas nama pemilik atau saham tanpa warkat. Jadi penyelesaian transaksi akan semakin cepat dan mudah karena tidak melalui surat, formulir dan prosedur yang berbelit-belit.

Indeks harga saham merupakan catatan terhadap perubahan-perubahan maupun pergerakan harga saham sejak mulai pertama kali beredar sampai pada suatu saat tertentu (Windijarto dan Nugroho, 2004). Setiap bursa memiliki beberapa macam indeks untuk mengukur pergerakan harga saham tersebut. Berbagai penyajian indeks tersebut bersifat spesifik agar investor dapat memanfaatkannya dalam strategi investasi di bursa saham.

Menurut Bursa Efek Indonesia (2010), indeks harga saham adalah suatu indikator yang menunjukkan pergerakan harga saham. Di Bursa Efek Indonesia terdapat sebelas jenis indeks, yaitu: (1) indeks individual, (2) indeks sektoral, (3) indeks harga saham gabungan (composite stock price index), (4) indeks lq45, (5) indeks syariah atau jii (jakarta islamic index), (6) indeks papan utama, (7) indeks kompas 100, (8) indeks papan pengembangan, (9) indeks bisnis-27, (10) indeks PEFINDO25, (11) indeks SRI-KEHATI.

Indeks harga saham gabungan (IHSG) merupakan indikator pergerakan harga semua saham yang tercatat di BEI, baik saham biasa maupun saham preferens. Selain itu, IHSG juga dapat menjadi barometer kesehatan ekonomi suatu Negara (Windijarto dan Nugroho, 2004). Angka IHSG dapat memberikan gambaran secara umum tentang perkembangan pasar modal di Indonesia dimana kenaikan/penurunan angka indeks harga saham dalam suatu periode merupakan indikasi naik atau turunnya perkembangan pasar modal. IHSG merupakan suatu rangkaian historis mengenai pergerakan 
harga saham gabungan sampai pada tanggal tertentu dan biasanya pergerakan harga saham tersebut disajikan setiap hari berdasarkan harga penutupan bursa pada hari tersebut.

\section{Anomali Pasar}

Menurut Jones (2007) anomali pasar adalah suatu teknik atau strategi yang bertentangan dengan pasar efisien. Hasil yang ditimbulkan oleh anomali pasar ini sangat berlawanan dengan apa yang dijelaskan oleh efisiensi pasar. Suatu anomali dapat disebut sebagai suatu ketidakteraturan yang memang eksis dan telah berlangsung lama di beberapa pasar modal. Studi literaturnya menyimpulkan bahwa sampai saat ini belum ada penjelasan yang memuaskan mengapa terjadi anomali pasar di suatu pasar modal negara tertentu tetapi tidak terjadi di pasar modal lainnya (Windijarto dan Nugroho, 2004).

Terdapat beberapa anomali pasar yang menarik perhatian: (1) Day of the week effect, yaitu perbedaan yang signifikan return saham pada hari tertentu dalam satu minggu dengan pendapatan pada hari-hari perdagangan lainnya (Windijarto dan Nugroho, 2004). Day of the week effect merupakan salah satu bentuk dari anomali seasonality yang banyak terjadi di berbagai pasar modal di dunia (Fitriani, 2009). Fenomena ini menggambarkan adanya perbedaan imbal hasil saham setiap harinya, yaitu terjadinya kecenderungan menurunnya imbal hasil saham pada hari Senin dan tingginya imbal hasil saham yang terjadi pada hari Jumat bila dibandingkan dengan hari-hari lainnya. Bahkan di beberapa negara, imbal hasil saham pada hari Senin menunjukkan presentase yang negatif bila dibandingkan dengan imbal hasil pada hari lainnya. Inti dari mempelajari keberadaan day of the week effect adalah diharapkan bahwa investor dapat menemukan waktu yang tepat dalam melakukan jualbeli saham sehingga diharapkan dapat memperoleh abnormal return yang ada di pasar; (2) Monthly effect, yaitu suatu gejala rata-rata pendapatan saham pada awal bulan yang diwakili oleh lima hari di awal bulan lebih besar/tinggi bila dibandingkan dengan rata-rata pendapatan saham pada hari perdagangan lainnya. Hal ini mungkin disebabkan karena cash flow yang diterima oleh investor di akhir bulan maupun di awal bulan mendorong investor untuk berspekulasi membeli saham berdasarkan informasi yang dimilikinya untuk mendapatkan keuntungan berupa capital gain (Windijarto dan Nugroho, 2004); (3) January effect - pada efek ini kecenderungan pendapatan saham pada bulan Desember mengalami penurunan dan kemudian meningkat pada bulan Januari. Tingkat keuntungan rata-rata saham pada bulan Januari lebih tinggi daripada bulan lainnya. Hal ini dapat terjadi karena dua hal. Pertama, kesan pajak yaitu para investor merealisasikan kerugian pajak (pajak yang sudah dicatat tapi belum dikeluarkan) bagi tujuan pajak mereka dan menginvestasikan semua ke dalam pasar modal pada tahun berikutnya. Kedua, akibat sistem kompensasi dalam industri sekuritas yaitu manager diberi bonus pada akhir tahun dan menginvestasikan jumlah tersebut pada awal tahun berikutnya (Windijarto dan Nugroho, 2004); (4) Holiday effect, yaitu gejala rata-rata pendapatan saham pada sehari sebelum hari libur akan lebih tinggi dibandingkan dengan rata-rata pendapatan saham pada hari perdagangan lainnya (Windijarto dan Nugroho, 2004).

\section{Nilai Tukar (Exchange rate)}

Menurut Adiningsih, dkk (1998), nilai tukar atau kurs rupiah adalah harga rupiah terhadap mata uang negara lain. Jadi nilai tukar rupiah merupakan nilai dari satu mata rupiah yang ditranslasikan ke dalam mata uang negara lain. Misalnya nilai tukar rupiah terhadap dollar AS, nilai tukar rupiah terhadap Yen, dan lain sebagainya. Nilai tukar merupakan satu indikator yang mempengaruhi aktivitas di pasar saham maupun pasar uang karena investor cenderung akan berhatihati untuk melakukan investasi. Menurunnya kurs Rupiah terhadap mata uang asing khususnya dollar AS memiliki pengaruh negatif terhadap ekonomi dan pasar modal (Sitinjak dan Kurniasari, 2003).

Nilai tukar atau kurs dibagi menjadi 2, yaitu: (1) kurs nominal yang merupakan harga relatif dari mata uang dua negara dan (2) kurs riil yaitu harga relatif dari barang-barang kedua negara. Dari kedua definisi diatas maka perhitungan kurs dapat diperoleh melalui perkalian antara kurs nominal dan 
rasio tingkat harga. Dimana rasio tingkat harga merupakan perbandingan antara harga barang domestik dan harga barang di luar negeri, misalnya di Amerika Serikat (Mankiw, 2000).

\section{Penelitian Terdahulu}

Ajayi dan Mougoue (1996) dalam penelitiannya yang berjudul On The Dynamic Relation Between Stock Prices and Exchange Rate meneliti hubungan dinamis antara harga saham dan nilai tukar pada "Delapan Besar" pasar saham, yaitu Kanada, Perancis, Jerman, Italia, Jepang, Belanda, Inggris, dan Amerika Serikat dengan menggunakan bivariate error correction model. Hasil penelitian mereka menunjukkan hubungan yang signifikan antara nilai tukar dan harga saham (pasar modal dan pasar uang). Adapun Prihantoro (2000) melakukan pengujian deskriptif mengenai pengaruh perdagangan harian saham dan exchange rate terhadap Indeks Harga Saham Gabungan (IHSG) di Bursa Efek Indonesia hasilnya menunjukkan bahwa hari Selasa mempunyai pengaruh terhadap IHSG, sedangkan untuk pengujian secara multivariat tidak satupun hari mempengaruhi IHSG. Untuk variabel makro exchange rate, hasil penelitiannya menunjukkan pengaruh yang signifikan. Sedangkan Budi dan Nurhatmini (2003) melakukan pengujian terkait dengan pengaruh hari perdagangan dan exchange rate terhadap return saham di Bursa Efek Indonesia. Hasil penelitiannya menyatakan bahwa hari Rabu mempunyai pengaruh terhadap Indeks LQ45 di Bursa Efek Indonesia. Walau demikian, berdasarkan uji multivariat, ternyata tidak terdapat pengaruh antara hari perdagangan terhadap Indeks LQ45, sedangkan exchange rate sangat berpengaruh terhadap Indeks LQ45.

\section{Kerangka Pemikiran}

Penelitian ini dilakukan terhadap dua variabel yang dianggap berpengaruh terhadap IHSG di BEI. Adapun variabel yang diprediksikan berpengaruh terhadap IHSG adalah variabel hari perdagangan saham dalam satu minggu dan nilai tukar Rupiah/US\$ yang merupakan variabel makro ekonomi (Gambar 2).

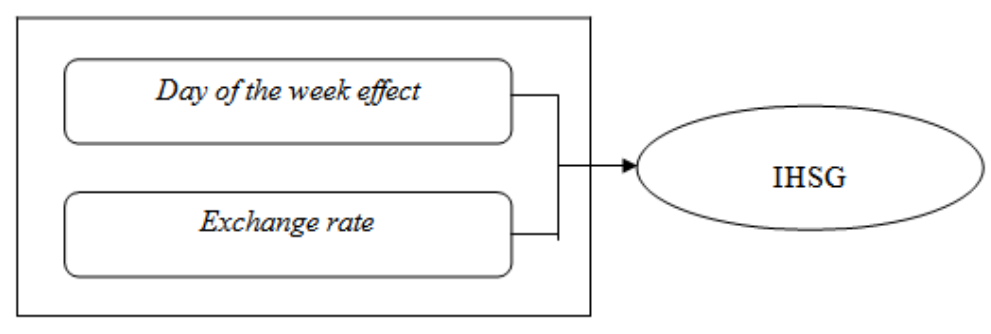

Gambar 2. Kerangka pemikiran.

\section{Hipotesis}

Hipotesis 1

Ho : Hari perdagangan dalam satu minggu (day of the week effect) secara parsial tidak berpengaruh signifikan terhadap IHSG di BEI.

$\mathrm{Ha}$ : Hari perdagangan dalam satu minggu (day of the week effect) secara parsial berpengaruh signifikan terhadap IHSG di BEI.

Hipotesis 2

Ho : Exchange rate secara parsial tidak berpengaruh signifikan terhadap IHSG di BEI.

$\mathrm{Ha}$ : Exchange rate secara parsial berpengaruh signifikan terhadap IHSG di BEI. 


\section{Hipotesis 3}

Ho : Hari perdagangan dalam satu minggu (day of the week effect) dan exchange rate secara simultan tidak berpengaruh signifikan terhadap IHSG di BEI.

$\mathrm{Ha}$ : Hari perdagangan dalam satu minggu (day of the week effect) dan exchange rate secara simultan berpengaruh signifikan terhadap IHSG di BEI.

\section{METODE}

\section{Objek Penelitian}

Objek penelitian ini adalah saham perusahaan yang terdaftar (listing) di Bursa Efek Indonesia yang berlokasi pada Jl. Jend. Sudirman Kav. 52-53, Jakarta Selatan.

\section{Pengumpulan Data}

Data yang digunakan dalam penelitian ini berupa data sekunder, yaitu data yang diperoleh dari sumber tertentu. Indeks harga dari BEI dan kurs Bank Indonesia. Indeks yang digunakan tersebut adalah Indeks Harga Saham Gabungan (IHSG), sedangkan nilai tukar yang digunakan adalah nilai tukar rupiah/US\$. Data sekunder meliputi IHSG harian dan nilai tukar rupiah/US\$ selama periode Januari sampai Desember 2009. Informasi mengenai data sekunder tersebut diperoleh dari Bursa Efek Indonesia dan Bank Indonesia. Data tersebut adalah data harga saham (harga penutupan) harian Indeks Harga Saham Gabungan dan nilai tukar rupiah/US\$ selama tahun 2009 pada hari Senin-Jumat. Oleh karena itu, sifat data awal yang digunakan adalah data time series (antar waktu) yang dikumpulkan selama kurun waktu tertentu (Gujarati, 2006). Jenis data yang digunakan dalam penelitian ini diperoleh dari situs resmi Bursa Efek Indonesia (www.idx.co.id) dan situs resmi Bank Indonesia (www.bi.go.id).

\section{Pengambilan Sampel}

Adapun metode pengambilan sampel penelitian ini adalah purposive sampling, yaitu metode pengambilan sampel dengan didasarkan pada kriteria tertentu (Sekaran, 2003). Kriteria sampel penelitian ini adalah saham perusahaan yang tercatat pada Indeks Harga Saham Gabungan dan nilai tukar rupiah/US\$ selama tahun 2009.

\section{Analisis Data}

Pola perubahan harga saham dalam penelitian ini ditunjukkan oleh pola IHSG. Pengujian pengaruh hari perdagangan dan exchange rate terhadap IHSG menggunakan persamaan regresi. IHSG sebagai variabel dependen dan hari perdagangan, yaitu hari Senin sampai dengan hari Jumat dan exchange rate sebagai variabel independen. Variabel hari perdagangan dalam persamaan regresi yang digunakan diperlakukan sebagai variabel dummy.

\section{Variabel Penelitian}

Variabel terikat (dependent variable), yaitu variabel tidak bebas dalam penelitian ini adalah IHSG. IHSG merupakan suatu nilai yang digunakan untuk mengukur kinerja gabungan seluruh saham yang tercatat di suatu bursa efek. Maksud dari gabungan seluruh saham ini adalah kinerja saham yang dimasukkan dalam perhitungan seluruh saham yang tercatat di bursa tersebut. 
Sedangkan variabel bebas (independent variable) dalam penelitian ini ada dua. Pertama, hari perdagangan dalam satu minggu (Day of the week) di BEI yaitu Senin sampai Jumat. Mengingat dalam satu minggu terdapat lima hari perdagangan, dalam model regresi dengan variabel dummy terdapat lima kategori yang menunjukkan hari Senin sampai dengan hari Jumat, yaitu:

Nilai Senin $=1$ untuk harga saham pada hari perdagangan Senin, sehingga harga saham pada hari perdagangan yang lain $=0$.

Nilai Selasa $=1$ untuk harga saham pada hari perdagangan Selasa, sehingga harga saham pada hari perdagangan yang lain $=0$.

Nilai Rabu $=1$ untuk harga saham pada hari perdagangan Rabu, sehingga harga saham pada hari perdagangan yang lain $=0$.

Nilai Kamis $=1$ untuk harga saham pada hari perdagangan Kamis, sehingga harga saham pada hari perdagangan yang lain $=0$.

Nilai Jumat $=1$ untuk harga saham pada hari perdagangan Jumat, sehingga harga saham pada hari perdagangan yang lain $=0$.

Variable bebas kedua adalah Exchange rate yaitu nilai tukar suatu mata uang suatu negara dengan mata uang negara lainnya (Ibrahim, 1995). Penelitian ini menggunakan nilai tukar rupiah terhadap dollar Amerika.

\section{Teknik Pengolahan Data}

\section{Uji Asumsi Klasik}

Pertama dilakukan uji normalitas. Priyatno (2008) menyatakan bahwa uji normalitas digunakan untuk mengetahui apakah populasi data terdistribusi normal atau tidak. Salah satu pengujian yang dapat dilakukan untuk pengujian normalitas yaitu dengan melakukan uji Jarque-Bera. Uji Jarque-Bera dapat dilakukan dengan melihat koefisien Jarque-Bera dan probabilitasnya. Kedua angka ini bersifat saling mendukung (Winarno, 2009). Bila nilai Jarque-Bera tidak signifikan (lebih kecil dari 2), data terdistribusi normal. Bila probabilitas lebih besar dari tingkat signifikansi, data terdistribusi normal. Pengujian normalitas juga dapat dilihat dengan normal probability plot yang membandingkan distribusi kumulatif dari distribusi normal. Distribusi normal akan membentuk satu garis lurus diagonal dan ploting akan dibandingkan dengan dengan garis diagonal. Jika data menyebar disekitar garis diagonal dan mengikuti garis diagonal, model regresi memenuhi asumsi normalitas (Ghozali, 2009).

Kedua dilakukan uji multikolinearitas yang dapat dilihat dari (1) nilai tolerance dan lawannya (2) Variance Inflation Factor (VIF). Jika nilai tolerance lebih besar dari 0,1 atau nilai VIF lebih kecil dari 10, dapat disimpulkan tidak terjadi multikolinearitas pada data yang akan diolah. Pengujian ketiga yaitu autokorelasi yang dapat dilakukan dengan Uji Durbin-Watson (Uji DW) untuk menghitung nilai d.

Selanjutnya dapat dilakukan uji heteroskedastisitash dengan menggunakan uji Glejser. Uji Glejser mendeteksi terjadinya heteroskedastisitas dengan meregresi nilai absolut residual terhadap variabel independen (Gurajati, 2006).

\section{Uji Statistik Deskriptif}

Statistik deskriptif memberikan gambaran atau deskripsi suatu data yang dilihat dari nilai ratarata (mean), standar deviasi, varian, nilai maksimum, nilai minimum sum, range, kurtosis dan skewness. Tujuan dari statistik deskriptif ini untuk mengetahui seberapa besar keakuratan data dan penyimpangan pada data tersebut (Ghozali, 2009). 


\section{Uji Multivariat}

Analisis statistik multivariat merupakan metode statistik yang memungkinkan kita melakukan penelitian terhadap lebih dari dua variabel secara bersamaan. Dengan menggunakan teknik analisis ini maka kita dapat menganalisis pengaruh beberapa variabel terhadap variable-variabel lainnya dalam waktu yang bersamaan.

Untuk melakukan uji multivariat digunakan model regresi linear berganda, sebagai berikut: $I N D E X t=a+b_{0} S E N I N+b_{1} S E L A S A+b_{2} R A B U+b_{3} K A M I S+b_{4} J U M A T+b_{5} E R+e$

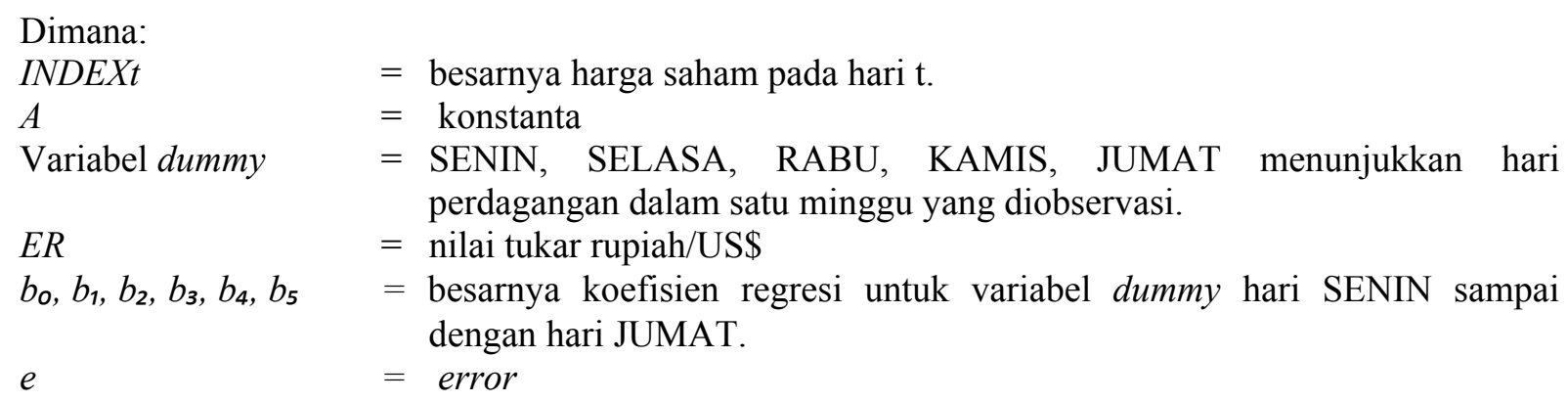

\section{Pengujian Hipotesis}

Pengujian hipotesis dilakukan dengan menggunakan analisis determinasi $\left(\mathrm{R}^{2}\right)$, uji koefisien regresi secara bersama-sama atau simultan (uji F), dan uji koefisien regresi secara individual atau parsial (uji t). Analisis determinasi dalam regresi linier berganda digunakan untuk mengetahui persentase sumbangan pengaruh variabel bebas secara serentak terhadap variabel terikat. Koefisien determinasi pada intinya mengukur seberapa jauh kemampuan model dalam menerangkan variasi variabel terikat. Untuk regresi dengan lebih dari dua variabel bebas digunakan adjusted $R^{2}$ sebagai koefisien determinasi. Uji F digunakan untuk mengetahui apakah variabel bebas secara bersama-sama berpengaruh signifikan terhadap variabel terikat. Uji ini juga dapat digunakan untuk mengetahui apakah model regresi dapat digunakan untuk memprediksi variabel terikat atau tidak. Uji t pada dasarnya menunjukkan seberapa jauh pengaruh satu variabel bebas secara individual dalam menerangkan variasi variabel terikat.

\section{HASIL DAN PEMBAHASAN}

\section{Gambaran Umum Objek Penelitian}

Indeks Harga Saham Gabungan (IHSG) merupakan indikator pasar modal yang digunakan untuk mengetahui aktivitas di pasar modal Indonesia. Hal ini dimungkinkan karena IHSG menunjukkan pergerakan harga saham secara umum yang tercatat di bursa efek. IHSG merupakan indeks yang paling banyak digunakan dan dipakai sebagai acuan tentang kegiatan di pasar modal. Pergerakan nilai indeks tersebut akan menunjukkan perubahan situasi pasar yang terjadi. Pasar yang sedang bergairah atau terjadi transaksi yang aktif ditunjukkan dengan indeks harga saham yang mengalami kenaikan, sedangkan yang lesu ditunjukkan dengan indeks harga saham yang mengalami penurunan. Indeks Harga Saham Gabungan (IHSG) atau juga dikenal dengan Jakarta Composite Index (JCI), mencakup pergerakan harga seluruh saham biasa dan saham preferen yang tercatat di BEI.

Sampai akhir 2008 lalu pasar modal Indonesia sempat diterpa krisis, hal ini terjadi akibat krisis subprime mortgage yang terjadi di Amerika Serikat. Sepanjang tahun 2008 itulah nilai indeks pasar modal di Indonesia mengalami penurunan. Karena hal tersebut pada awal tahun 2009 tren pergerakan nilai Indeks Harga Saham Gabungan relatif masih kurang bagus. Seiring berjalannya 
waktu nilai indeks pada tahun 2009 mengalami peningkatan hingga akhir tahun. Peningkatan kondisi saham pasar modal di Indonesia, dapat dilihat dari grafik IHSG selama tahun 2009 berikut ini (Gambar 3).

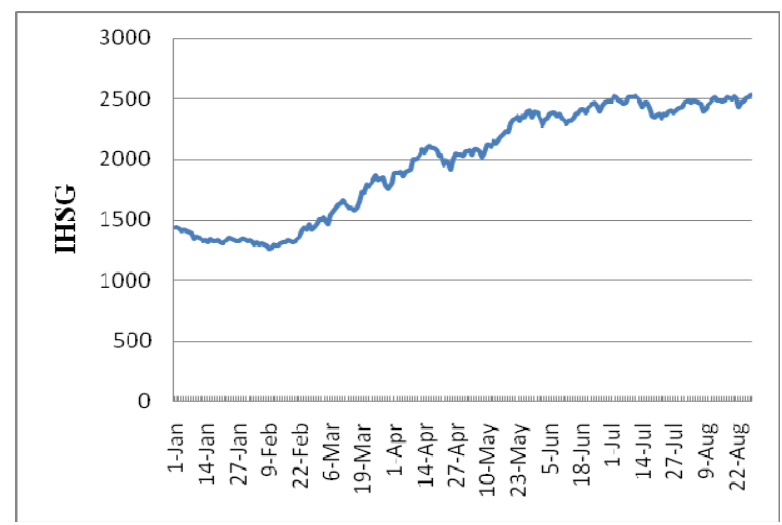

Gambar 3. Grafik IHSG Tahun 2009 (Data penelitian yang diolah, 2010)

Dari gambar 4.1 di atas, dapat dilihat bahwa kondisi saham di pasar modal Indonesia benarbenar terbukti mengalami peningkatan. Hal ini dapat dilihat pada awal tahun 2009 IHSG berada pada indeks 1437.338 dan pada akhir tahun meningkat ke 2534.356. Hal tersebut mengindikasikan bahwa harga saham secara keseluruhan di BEI pada tahun 2009 mengalami peningkatan.

\section{Hasil Penelitian}

\section{Uji Normalitas}

Berdasarkan hasil uji normalitas yang telah dilakukan penulis dengan metode Jarque-Bera, didapatkan nilai probabilitas sebesar 0.47 yang melebihi $\alpha=5 \%$ sehingga mencerminkan bahwa data tersebut terdistribusi normal (Gambar 4).

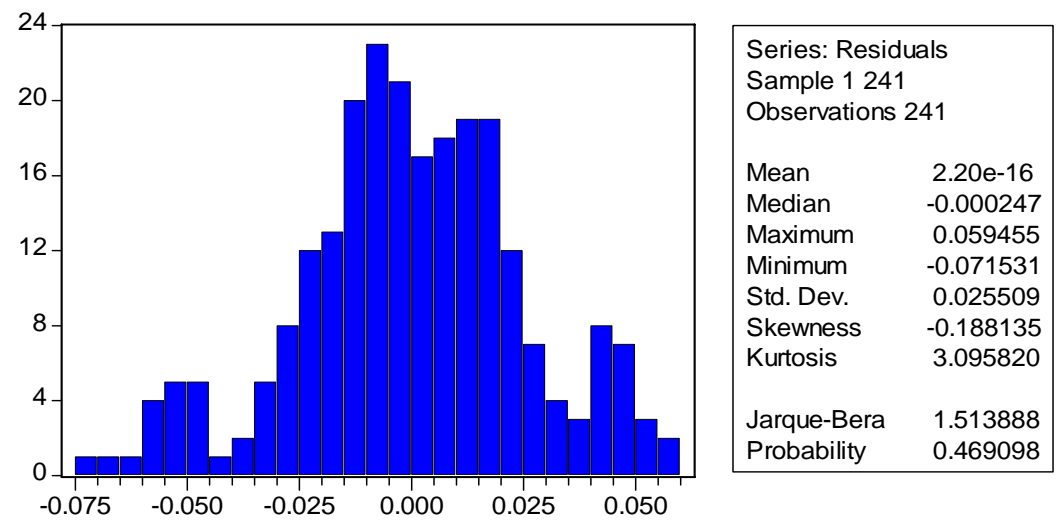

Gambar 4. Grafik hasil uji normalitas.

\section{Uji Multikolinearitas}

Hasil penelitian ini bebas dari gejala multikolinearitas. Hal ini dibuktikan dengan ketentuan nilai VIF kurang dari 10 dan tolerance lebih besar dari 0.1 sesuai yang tercantum pada Tabel 1 , sehingga dapat disimpulkan tidak terjadi masalah multikolinearitas. 
Tabel 1Hasil Uji Multikolinearitas

Coefficients $^{\mathrm{a}}$

\begin{tabular}{|c|c|c|c|c|c|c|c|}
\hline \multirow[b]{2}{*}{ Model } & \multicolumn{3}{|c|}{ Unstandardized Coefficients Standardized Coefficients } & \multirow[b]{2}{*}{$\mathrm{t}$} & \multirow[b]{2}{*}{ Sig. } & \multicolumn{2}{|c|}{ Collinearity Statistics } \\
\hline & $\mathrm{B}$ & Std. Error & Beta & & & Tolerance & VIF \\
\hline 1 (Constant) & 15.265 & .193 & & 78.960 & .000 & & \\
\hline Senin & -.001 & .005 & -.006 & -.287 & .774 & .646 & 1.547 \\
\hline Rabu & .000 & .005 & .000 & -.020 & .984 & .637 & 1.570 \\
\hline Kamis & $-3.783 \mathrm{E}-6$ & .005 & .000 & .000 & .999 & .646 & 1.547 \\
\hline Jumat & .001 & .005 & .004 & .208 & .836 & .650 & 1.539 \\
\hline Exchange_rate & -2.982 & .048 & -.971 & -61.988 & .000 & .999 & 1.001 \\
\hline
\end{tabular}

a. Dependent Variable: Harga_saham

\section{Uji Autokorelasi}

Hasil penelitian ini ternyata terdapat autokorelasi. Berdasarkan hasil hitung (Tabel 2), nilai Durbin-Watson (DW-test) adalah sebesar 0,138 sedangkan dalam DW-tabel untuk $\mathrm{k}=2$ dan $\mathrm{n}=241$, besarnya DW-tabel; dL (DW batas bawah) $=1,748$; dU (DW batas atas $)=1,789$; 4-dU = 2,211; dan 4$\mathrm{dL}=2,252$. Dari hasil uji Durbin-Watson di atas maka terjadi autokorelasi (Gambar 5).

Tabel 2 Hasil Uji Autokorelasi Durbin-Watson

\begin{tabular}{|c|c|c|c|c|c|}
\hline \multicolumn{6}{|c|}{ Model Summary } \\
\hline Model & $\mathrm{R}$ & R Square & $\begin{array}{l}\text { Adjusted R } \\
\text { Square }\end{array}$ & $\begin{array}{l}\text { Std. Error of the } \\
\text { Estimate }\end{array}$ & Durbin-Watson \\
\hline 1 & $.971^{\mathrm{a}}$ & .942 & .941 & .02576599 & .138 \\
\hline
\end{tabular}

a. Predictors: (Constant), Exchange_rate, Rabu, Jumat, Kamis, Senin

b. Dependent Variable: Harga_saham

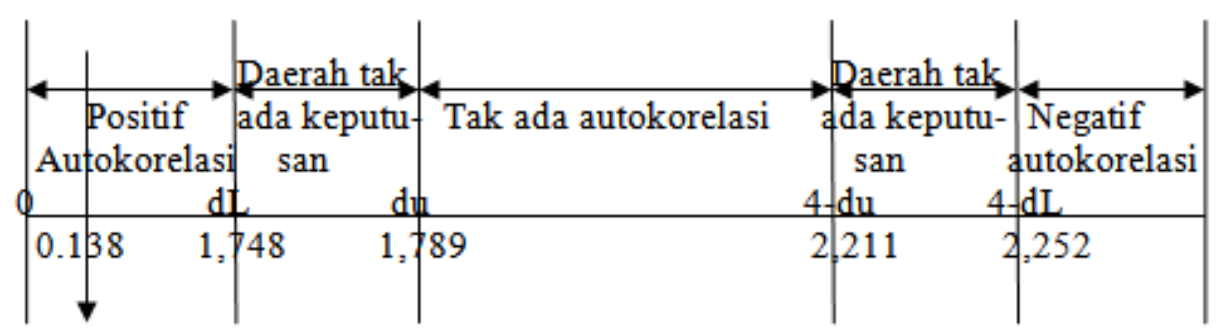

Gambar 5. Keputusan uji autokorelasi Durbin-Watson.

\section{Uji Heteroskedastisitas}

Tidak terjadi heteroskedastisitas pada model regresi penelitian ini. Hal tersebut dapat disimpulkan dari nilai signifikansi pada tabel output sebesar 0.191 yang lebih besar dari $\alpha$ sebesar 5\% (Tabel 3). 
Tabel 3 Hasil Uji Heteroskedastisitas

\begin{tabular}{llrrrrr}
\hline \multicolumn{7}{c}{ ANOVA $^{\mathbf{b}}$} \\
Model & & Sum of Squares & df & Mean Square & F & Sig. \\
\hline 1 & Regression & .002 & 5 & .000 & 1.498 & $.191^{\text {a }}$ \\
& Residual & .059 & 235 & .000 & & \\
& Total & .061 & 240 & & & \\
\hline
\end{tabular}

a.Dependent Variable: abresid

Sumber: Data penelitian yang diolah (2010)

\section{Uji Statistik Deskriptif}

Berdasarkan hasil analisis statistik deskriptif (Tabel 4) menunjukkan bahwa selama tahun 2009 perdagangan saham paling sering terjadi pada hari Selasa, dengan rata-rata tingkat indeks sebesar 1256 serta tingkat nilai tukar rupiah terhadap dollar AS sebesar Rp9970/US\$.

Tabel 4 Hasil Analisis Statistik Deskriptif

\begin{tabular}{lrrrr}
\multicolumn{5}{c}{ Statistics } \\
& INDEX & WKDAY & DOLLAR \\
\hline $\mathrm{N}$ & Valid & 241 & 241 & 241 \\
& Missing & 0 & 0 & 0 \\
Mean & $1.98066 \mathrm{E} 3$ & 2.9751 & $1.0454 \mathrm{E} 4$ \\
Mode & $1.256 \mathrm{E} 3^{\mathrm{a}}$ & 2.00 & 9970.00 \\
Std. Deviation & $4.513964 \mathrm{E} 2$ & 1.39918 & $8.49521 \mathrm{E} 2$ \\
& $2.038 \mathrm{E} 5$ & 1.958 & $7.217 \mathrm{E} 5$ \\
Variance & $1.256 \mathrm{E} 3$ & 1.00 & 9339.00 \\
Minimum & $2.534 \mathrm{E} 3$ & 5.00 & $1.21 \mathrm{E} 4$ \\
Maximum &
\end{tabular}

a. Multiple modes exist. The smallest value is shown

\section{Uji Multivariat}

Untuk melihat pengaruh hari perdagangan terhadap Indeks Harga Saham Gabungan (IHSG), akan dilakukan pengujian multivariat (Tabel 5) dengan menggunakan regresi linear berganda. Penggunaan exchange rate sebagai variabel kontrol diharapkan mampu mengurangi dan mengendalikan bias yang akan terjadi yang disebabkan oleh fluktuasi nilai tukar rupiah terhadap dollar AS. Pemilihan exchange rate sebagai variabel kontrol karena secara logika merupakan variabel yang relatif tidak dipengaruhi oleh intervensi pemerintah dibandingkan dengan variabel makro lain, seperti tingkat bunga dan inflasi. Di samping itu dalam pengujian multivariat ini variabel dependen dan independen dilog-kan terlebih dahulu. Hal ini dimaksudkan untuk mengurangi kesenjangan yang terlalu besar antar variabel tersebut diatas dengan variabel-variabel hari yang merupakan variabel dummy.

Regresi linear berganda yang digunakan adalah Backward Stepwise Linear Regression Model. Hal ini dimaksudkan agar bisa melihat berbagai kemungkinan terbaik yang akan terjadi apabila setiap variabel independen yang paling tidak signifikan pengaruhnya terhadap variabel dependen dikeluarkan dari model regresi berganda (secara otomatis mengeliminasi variabel yang paling tidak signifikan). 
Tabel 5 Hasil Analisis Multivariat

\begin{tabular}{|c|c|c|c|c|c|c|}
\hline \multicolumn{7}{|c|}{ Coefficients $^{\mathrm{a}}$} \\
\hline \multirow{2}{*}{\multicolumn{2}{|c|}{ Model }} & \multicolumn{2}{|c|}{ Unstandardized Coefficients } & \multirow{2}{*}{$\begin{array}{c}\text { Standardized } \\
\text { Coefficients }\end{array}$} & \multirow[b]{2}{*}{$\mathrm{t}$} & \multirow[b]{2}{*}{ Sig. } \\
\hline & & B & Std. Error & & & \\
\hline \multirow[t]{6}{*}{1} & (Constant) & 15.265 & .193 & & 78.960 & .000 \\
\hline & Senin & -.001 & .005 & -.006 & -.287 & .774 \\
\hline & Rabu & .000 & .005 & .000 & -.020 & .984 \\
\hline & Kamis & $-3.783 \mathrm{E}-6$ & .005 & .000 & .000 & .999 \\
\hline & Jumat & .001 & .005 & .004 & .208 & .836 \\
\hline & Exchange_rate & -2.982 & .048 & -.971 & -61.988 & .000 \\
\hline \multirow[t]{5}{*}{2} & (Constant) & 15.265 & .193 & & 79.159 & .000 \\
\hline & Senin & -.001 & .005 & -.006 & -.328 & .743 \\
\hline & Rabu & .000 & .004 & .000 & -.023 & .982 \\
\hline & Jumat & .001 & .005 & .004 & .237 & .813 \\
\hline & Exchange_rate & -2.982 & .048 & -.971 & -62.127 & .000 \\
\hline \multirow[t]{4}{*}{3} & (Constant) & 15.265 & .192 & & 79.327 & .000 \\
\hline & Senin & -.001 & .004 & -.005 & -.340 & .734 \\
\hline & Jumat & .001 & .004 & .004 & .260 & .795 \\
\hline & Exchange_rate & -2.982 & .048 & -.971 & -62.260 & .000 \\
\hline \multirow[t]{3}{*}{4} & (Constant) & 15.265 & .192 & & 79.489 & .000 \\
\hline & Senin & -.002 & .004 & -.006 & -.415 & .678 \\
\hline & Exchange_rate & -2.982 & .048 & -.971 & -62.391 & .000 \\
\hline \multirow[t]{2}{*}{5} & (Constant) & 15.263 & .192 & & 79.637 & .000 \\
\hline & Exchange_rate & -2.981 & .048 & -.971 & -62.502 & .000 \\
\hline
\end{tabular}

a. Dependent Variable: Harga_saham

Pada model (1) semua variabel hari perdagangan dimasukkan dalam pengujian. Hasil pengujian menunjukkan bahwa sisa empat hari perdagangan tersebut mendukung hipotesis pertama atau dengan kata lain bahwa hari perdagangan saham tidak bepengaruh terhadap IHSG dengan tingkat signifikansi $>0.05$. Variabel kontrol yaitu exchange rate memiliki koefisien regresi lebih besar dari keseluruhan hari perdagangan (-2.982) dan mempunyai tingkat signifikansi yang sangat besar $(0.000<0.05)$, sehingga hipotesis kedua tidak didukung atau dengan kata lain bahwa exchange rate sangat berpengaruh terhadap IHSG. Pada model (2) setelah variabel independen yang paling tidak signifikan dikeluarkan, yaitu hari Kamis, ternyata hasilnya tidak jauh berbeda dengan model (1) meskipun terdapat sedikit perubahan pada tingkat signifikansi. Sehingga pada model (2) hipotesis pertama didukung dan hipotesis kedua tidak didukung. Dalam model (3) setelah hari Rabu sebagai variabel independen yang paling tidak signifikan dikeluarkan, hasil pengujian juga tidak jauh berbeda dengan model (1) dan (2). Pengujian dalam model (4), dengan mengeluarkan hari Jumat sebagai variabel independen yang paling tidak signifikan, hasilnya juga tidak jauh berbeda dengan dengan model (1), (2) dan (3). Hari Senin mempunyai tingkat signifikansi lebih besar dari 5\%, sehingga hipotesis pertama didukung. Sedangkan variabel kontrol mempunyai koefisien regresi yang cukup tinggi $(-2.982)$ dan mempunyai tingkat signifikan yang sangat besar $(0.000<0.05)$, sehingga hipotesis kedua tidak didukung.

Pada model (5) secara jelas memperlihatkan hanya variabel exchange rate mempunyai tingkat signifikansi yang sangat besar, atau dengan $p$ value lebih kecil dari tingkat $\alpha 5 \%$ dan menunjukkan koefisien regresi negatif sebesar (-2.981). Sehingga hipotesis kedua tidak didukung atau dengan kata lain exchange rate berpengaruh terhadap IHSG. Hal ini sangat memperlihatkan bahwa exchange rate sangat mempengaruhi Indeks Harga Saham Gabungan (IHSG) di BEI meskipun berpengaruh negatif. 
Berdasarkan model (5) pada Tabel 5 di atas diperoleh model persamaan regresi linear berganda seperti berikut:

$$
\text { INDEXt }=15.263-2.981 \mathrm{ER}
$$

Dari model regresi tersebut diperoleh konstanta sebesar 15.263. Hal ini berarti bahwa tanpa adanya rasio hari perdagangan dan nilai tukar rupiah/US\$ akan terjadi perubahan IHSG sebesar $15.263 \%$. Sedangkan nilai tukar rupiah/US \$ mempunyai koefisien regresi sebesar -2.981 dan bertanda negatif, hal ini berarti setiap perubahan nilai tukar rupiah/US\$ satu persen dengan asumsi variabel lainnya dianggap tetap maka IHSG akan mengalami perubahan sebesar $-2.981 \%$.

\section{Koefisien Determinasi (Adjusted $\mathbf{R}^{2}$ ) dan Koefisien Korelasi Parsial $\left(\mathbf{r}^{2}\right)$}

Berikut ini adalah tabel yang memuat model summary (Tabel 6)

Tabel 6 Model Summary

\begin{tabular}{lrrrr}
\hline Model & R & R Square & Adjusted R Square & Std. Error of the Estimate \\
\hline 1 & $.971^{\mathrm{a}}$ & .942 & .941 & .02576599 \\
2 & $.971^{\mathrm{b}}$ & .942 & .941 & .02571135 \\
3 & $.971^{\mathrm{c}}$ & .942 & .942 & .02565707 \\
4 & $.971^{\mathrm{d}}$ & .942 & .942 & .02560676 \\
5 & $.971^{\mathrm{e}}$ & .942 & .942 & .02556238 \\
\hline
\end{tabular}

a. Predictors: (Constant), Exchange_rate, Rabu, Jumat, Kamis, Senin

b. Predictors: (Constant), Exchange_rate, Rabu, Jumat, Senin

c. Predictors: (Constant), Exchange_rate, Jumat, Senin

d. Predictors: (Constant), Exchange_rate, Senin

e. Predictors: (Constant), Exchange_rate

Terlihat bahwa dari keseluruhan model yang dihasilkan mempunyai nilai Adjusted $\mathrm{R}^{2}$ yang sangat tinggi, yaitu sebesar 94\%. Hal ini menunjukkan bahwa tingkat kemampuan menjelaskan kedua variabel independen juga sangat tinggi.

Berdasarkan tabel 6 terlihat bahwa masing-masing variabel independen (hari perdagangan dan nilai tukar rupiah/US\$) terhadap variabel dependen (IHSG) memiliki hubungan yang sangat kuat, yaitu sebesar $94 \%$.

\section{Uji $t$}

Berikut ini adalah tabel hasil uji $t$ (Tabel 7)

Tabel 7 Hasil Uji $T_{\text {test }}$ Coefficients $^{\mathrm{a}}$

\begin{tabular}{|c|c|c|c|c|c|c|}
\hline \multirow[b]{2}{*}{ Mod } & & \multicolumn{2}{|c|}{ Unstandardized Coefficients } & \multirow{2}{*}{$\begin{array}{c}\text { Standardized } \\
\text { Coefficients }\end{array}$} & \multirow[b]{2}{*}{$\mathrm{t}$} & \multirow[b]{2}{*}{ Sig. } \\
\hline & & $\mathrm{B}$ & Std. Error & & & \\
\hline \multirow[t]{6}{*}{1} & (Constant) & 15.265 & .193 & & 78.960 & .000 \\
\hline & Senin & -.001 & .005 & -.006 & -.287 & .774 \\
\hline & Rabu & .000 & .005 & .000 & -.020 & .984 \\
\hline & Kamis & $-3.783 \mathrm{E}-6$ & .005 & .000 & .000 & .999 \\
\hline & Jumat & .001 & .005 & .004 & .208 & .836 \\
\hline & Exchange rate & -2.982 & .048 & -.971 & -61.988 & .000 \\
\hline
\end{tabular}

a. Dependent Variable: Harga_saham 
Pengujian hipotesis (1) penelitian ini yang menggunakan uji statistik Ttest memiliki hipotesis sebagai berikut:

Ho: Hari perdagangan dalam satu minggu (day of the week effect) secara parsial tidak berpengaruh singnifikan terhadap IHSG di BEI.

Ha: Hari perdagangan dalam satu minggu (day of the week effect) secara parsial berpengaruh signifikan terhadap IHSG di BEI.

Dengan menggunakan tingkat signifikansi $5 \%(\alpha=0.05)$ dan degree of freedom $=$ tak terhingga $(\infty)$ diperoleh $t_{\text {tabel }}$ sebesar 1,645. Dari hasil uji pada tabel 7 di atas dihasilkan $t_{\text {hitung }}$ masingmasing hari sebesar $-0.287,-0.020,0.000,0.208$ sehingga $t_{\text {hitung }}$ lebih kecil dari $t_{\text {tabel }}(-0.287,-0.020$, $0.000,0.208<1.645$ ). Nilai signifikansi juga menunjukkan lebih besar dari 0.05 yaitu sebesar 0.774 , $0.985,0.999,0.838$ dari masing-masing hari perdagangan, sehingga tidak dapat menolak/menerima Ho dan menolak Ha. Hal ini berarti bahwa variabel hari perdagangan dalam satu minggu (day of the week effect) secara parsial tidak mempunyai pengaruh signifikan terhadap IHSG di BEI.

Pengujian hipotesis (2) penelitian ini yang menggunakan uji statistik Ttest memiliki hipotesis sebagai berikut:

Ho: Exchange rate secara parsial tidak berpengaruh singnifikan terhadap IHSG di BEI.

Ha: Exchange rate secara parsial berpengaruh signifikan terhadap IHSG di BEI.

Dengan menggunakan tingkat signifikansi $5 \%(\alpha=0.05)$ dan degree of freedom $=$ tak terhingga $(\infty)$ diperoleh $t_{\text {tabel }}$ sebesar 1,645. Dari hasil uji pada tabel 7 di atas dihasilkan $t_{\text {hitung }}$ sebesar 61.988 sehingga $t_{\text {hitung }}$ lebih besar dari $t_{\text {tabel }}(-61.988>1.645)$. Nilai signifikansi juga menunjukkan lebih kecil dari 0.05 yaitu sebesar 0.000 , sehingga menolak Ho dan menerima Ha. Hal ini berarti bahwa variabel exchange rate secara parsial mempunyai pengaruh signifikan terhadap IHSG di BEI.

\section{Uji F}

Berikut ini adalah tabel hasil uji $F$ (Tabel 8).

Tabel 8 Hasil Uji Ftest

ANOVA $^{\text {b }}$

\begin{tabular}{llrrrrr}
\hline Model & & Sum of Squares & df & Mean Square & F & \multicolumn{1}{c}{ Sig. } \\
\hline 1 & Regression & 2.553 & 5 & .511 & 769.046 & $.000^{\mathrm{a}}$ \\
& Residual & .156 & 235 & .001 & & \\
& Total & 2.709 & 240 & & & \\
\hline
\end{tabular}

a. Predictors: (Constant), Exchange_rate, Rabu, Jumat, Kamis, Senin

b. Dependent Variable: Harga_saham

Pengujian hipotesis (3) penelitian ini yang menggunakan uji statistik Ftest memiliki hipotesis sebagai berikut:

Ho: Hari perdagangan dalam satu minggu (day of the week effect) dan exchange rate secara simultan tidak berpengaruh singnifikan terhadap IHSG di BEI.

Ha: Hari perdagangan dalam satu minggu (day of the week effect) dan exchange rate secara simultan berpengaruh signifikan terhadap IHSG di BEI.

Pengujian hipotesis ketiga dilakukan dengan uji $\mathrm{F}$ seperti terlihat pada tabel 4.8 di atas. Pengujian ini bertujuan untuk mengetahui apakah variabel independen secara bersama-saama memiliki pengaruh terhadap variabel dependen. Dengan menggunakan tingkat signifikansi 5\% $(\alpha=0.05)$, degree of freedom $=$ tak terhingga $(\infty)$ dan numerator degree of freedom $=$ tak terhingga $(\infty)$ diperoleh 
$F_{\text {tabel }}$ sebesar 1,00. Dari hasil uji pada tabel 4.8 di atas dihasilkan $F_{\text {hitung }}$ sebesar 769,046 sehingga $F_{\text {hitung }}$ lebih besar dari $\mathrm{F}_{\text {tabel }}(769,046>1,00)$. Nilai signifikansi juga menunjukkan lebih kecil dari 0.05 yaitu sebesar 0.000 , sehingga menolak Ho dan menerima Ha. Hal ini berarti bahwa kedua variabel independen hari perdagangan dalam satu minggu (day of the week effect) dan exchange rate secara simultan mempunyai pengaruh signifikan terhadap IHSG di BEI.

\section{Pembahasan Hasil Penelitian}

Indeks harga Saham Gabungan yang mencerminkan pergerakan keseluruhan harga saham perusahaan-perusahaan yang terdaftar di Bursa Efek Indonesia merupakan indikator yang dapat memberikan gambaran secara umum tentang perkembangan pasar modal di Indonesia, dimana kenaikan/penurunan angka indeks harga saham dalam suatu periode merupakan indikasi naik turunnya perkembangan pasar modal. IHSG merupakan suatu rangkaian historis mengenai pergerakan harga saham gabungan sampai pada tanggal tertentu dan biasanya pergerakan harga saham tersebut disajikan setiap hari perdagangan berdasarkan harga penutupan bursa pada hari tersebut.

Day of the week effect menunjukkan adanya perbedaan yang signifikan return saham pada hari tertentu dalam satu minggu dengan pendapatan pada hari-hari perdagangan lainnya. Dalam hal ini harga saham suatu perusahaan dapat mencerminkan return yang akan diterima oleh perusahaan tersebut. Namun dalam hasil penelitian ini day of the week effect ternyata tidak memiliki pengaruh yang signifikan terhadap IHSG. Hal ini disebabkan karena hari perdagangan dalam satu minggu tidak menunjukkan adanya indikasi yang nyata.

Berdasarkan hasil uji hipotesis secara parsial ternyata hari perdagangan tidak mempunyai pengaruh terhadap IHSG karena nilai $t_{\text {hitung }}$ lebih kecil dari $t_{\text {tabel }}(-0.287,-0.020,0.000,0.208<1.645)$. Berdasarkan uji multivariat, ternyata juga tidak terdapat pengaruh antara hari perdagangan terhadap IHSG. Artinya, Ho diterima yang mengindikasikan bahwa hari perdagangan dalam satu minggu tidak mempunyai pengaruh signifikan terhadap IHSG. Hal ini bukan menjadi bahan pertimbangan investor untuk melakukan transaksi jual atau beli saham, karenanya investor tidak perlu mengkhawatirkan adanya perubahan pola pergerakan harga saham yang disebabkan perubahan hari perdagangan. Hasil uji tersebut mendukung pengujian yang dilakukan oleh Heru Prihantoro (2000) yang juga didukung oleh Ichsan Setiyo Budi dan Erni Nurhatmi (2003) yang menyatakan bahwa hari perdagangan tidak mempengaruhi IHSG.

Exchange rate sebagai salah satu indikator yang mempengaruhi aktivitas di pasar saham maupun pasar uang, oleh karena itu investor cenderung akan berhati-hati untuk melakukan investasi. Dari hasil penelitian ini, ternyata exchange rate memang berpengaruh sangat signifikan terhadap IHSG, meskipun pengaruhnya negatif hal tersebut memang mengindikasikan keadaan yang sebenarnya terjadi. Hal ini dapat dilihat jika perubahan kurs valas (yang diwakili oleh US\$) memberikan dampak bagi pasar modal, karena apabila kurs valas menguat maka investor akan menjual seluruh atau sebagian sahamnya dan dialihkan pada valas untuk kemudian diinvestasikan ke tempat lain sebagai tabungan, sehingga harga saham akan turun. Sebaliknya, jika kurs valas melemah, investor akan beramai-ramai membeli mata uang domestik untuk diinvestasikan pada saham sehingga harga saham akan cenderung meningkat.

Setelah dilakukan uji hipotesis secara parsial exchange rate mempunyai pengaruh terhadap IHSG karena nilai $t_{\text {hitung }}$ lebih besar dari $t_{\text {tabel }}(-61.988>1.645)$. Hal ini dapat dijelaskan bahwa terjadinya fluktuasi nilai tukar rupiah terhadap mata uang asing (dollar AS) akan memberikan dampak terhadap iklim investasi dalam negeri, terutama pasar modal. Ketika terjadi apresiasi kurs rupiah misalnya, akan berdampak pada perkembangan pemasaran produk Indonesia di luar negeri, terutama dalam hal persaingan harga. Sebaliknya, bila terjadi depresiasi rupiah terhadap dollar AS akan berdampak pada perusahaan-perusahaan go public, terutama yang menggantungkan faktor produksi 
terhadap bahan-bahan impor, sehingga biaya produksi meningkat, laba yang diperoleh menurun dan akan berakibat jatuhnya harga saham perusahaan tersebut. Sehingga secara tidak langsung akan mempengaruhi Indeks Harga Saham Gabungan.

Hasil penelitian ini sesuai dengan penelitian yang dilakukan oleh Ajayi dan Mougoue (1996) yang menunjukkan adanya hubungan dinamis antara harga saham dan nilai tukar pada "Delapan Besar" pasar saham, yaitu Kanada, Perancis, Jerman, Italia, Jepang, Belanda, Inggris, dan Amerika Serikat. Hasil penelitian mereka menunjukkan hubungan yang signifikan antara nilai tukar dan harga saham. Demikian juga penelitian Sudjono (2002) serta Sitinjak dan Kurniasari (2003), memiliki pendapat yang sama bahwa variabel ekonomi makro yang diwakilkan dengan nilai tukar rupiah/US\$ mempunyai pengaruh yang signifikan terhadap indeks harga saham.

\section{PENUTUP}

\section{Kesimpulan}

Berdasarkan hasil penelitian dan pembahasan analisis pada penelitian ini, dapat ditarik kesimpulan bahwa: (1) Berdasarkan hasil uji $t$ dan hasil analisis multivariat ternyata tidak ada satupun hari perdagangan dalam satu minggu yang berpengaruh signifikan terhadap Indeks Harga Saham Gabungan (IHSG) di Bursa Efek Indonesia tahun 2009; (2) Berdasarkan hasil uji $t$ dan hasil analisis multivariat, ternyata exchange rate mempunyai pengaruh signifikan terhadap Indeks Harga Saham Gabungan (IHSG) di Bursa Efek Indonesia tahun 2009; (3) Berdasarkan hasil uji $F$, ternyata Indeks Harga Saham Gabungan (IHSG) di Bursa Efek Indonesia tahun 2009 dipengaruhi oleh hari perdagangan dalam satu minggu dan exchange rate.

\section{Saran}

Saran yang dapat diberikan oleh penulis setelah melakukan penelitian ini adalah: (1) Investor agar lebih memperhatikan pola IHSG dan fluktuasi nilai tukar rupiah/US\$ sebagai bahan pertimbangan untuk melakukan pemngambilan keputusan sebelum melakukan kegiatan investasi; Pemerhati pasar modal agar dapat menggunakan hasil penelitian ini sebagai salah satu bahan acuan dalam memberikan informasi mengenai bursa kepada masyarakat, terutama dalam keefisiensian Bursa Efek Indonesia; (3) Pembaca atau akademisi yang ingin melakukan penelitian tentang anomaly market diharapkan menggunakan lebih dari satu macam indeks harga saham yang terdapat di BEI untuk mengetahui perbedaan dari pengaruh masing-masing indeks; serta menambah variabel makro agar dapat mengetahui pengaruh dan perbandingan dari masing-masing variabel makro yang diteliti.

\section{DAFTAR PUSTAKA}

Adiningsih, Sri dkk. (1998). Perangkat Analisis dan Teknik Analisis Investasi di Pasar Modal Indonesia. Jakarta: PT. Bursa Efek Jakarta.

Ajayi, R.A dan M. Mougoue. 1996. On The Dynamic Relation Between Stock Prices and Exchange Rate. Journal of Finance Research, 19; 193-207.

Budi, Ichsan Setiyo dan Erni Nurhatmini. (2003). Pengaruh Hari Perdagangan dan Exchange Rate Terhadap Return Saham di Bursa Efek Jakarta. Jurnal Manajemen dan Bisnis, 5 (1), 47-26. 
Fitriani, Dwita Amelia. (2009). Analisis Day of the Week Effect Terhadap Imbal Hasil IHSG Serta Kaitannya Dengan Risiko Pasar Modal Periode 2003-2007. Skripsi tidak diterbitkan. Depok: Universitas Indonesia.

Ghozali, Imam. (2009). Aplikasi Analisis Multivariate Dengan Program SPSS. Semarang: Badan Penerbit Universitas Diponegoro.

Gujarati, Damodar. 2006. Dasar-dasar Ekonometrika, edisi ketiga. Jakarta: Erlangga.

Husnan, Suad. 2009. Dasar-dasar Teori Portofolio dan Analisis Sekuritas, edisi keempat. Yogyakarta: UPP STIM YKPN.

Jones, Charles P. (2007). Investment: Analysis and Management, $10^{\text {th }}$ edition. New York: John Wiley and Sons.

Prihantoro, Heru. (2000). Pengaruh Hari Perdagangan Harian Saham dan Exchange Rate Terhadap IHSG di Bursa Efek Jakarta. Thesis S2. Yogyakarta: Universitas Gajah Mada.

Sekaran, Uma. (2003). Metodologi Penelitian untuk Bisnis. Jakarta: Salemba Empat.

Sitinjak, E. L.M dan Kurniasari, W. (2003). Indikator-indikator Pasar Saham dan Pasar Uang yang Saling Berkaitan Ditinjau dari Pasar Saham sedang Bullish dan Bearish. Jurnal Riset Ekonomi dan Manajemen, 3 (3).

Sunariyah. (2006). Pengantar Pengetahuan Pasar Modal. Yogyakarta: UPP STIM YKPN.

Tandelilin, Eduardus. (2010). Portofolio dan Investasi: Teori dan Aplikasi, edisi Pertama. Yogyakarta: Kanisius.

Windijarto, Sasikirono, Nugroho. (2004). Pengaruh Hari Dalam Satu Minggu Terhadap Pendapatan Saham Investor. Surabaya: Fakultas Ekonomi Universitas Airlangga. 